\title{
Online Corporate Social Responsibility Reporting in the Croatian Banking Sector ${ }^{1}$
}

\author{
Sanda Grudić Kvasić \\ University of Rijeka, Faculty of Tourism and Hospitality Management, Opatija, \\ Croatia \\ sandagrudic@gmail.com \\ Ljerka Cerović \\ University of Rijeka, Faculty of Economics, Rijeka, Croatia \\ cerovic@efri.hr
}

Bojana Olgić Draženović

University of Rijeka, Faculty of Economics, Rijeka, Croatia

bolgic@inet.hr

\section{ABSTRACT}

In the past few decades, the concept of corporate social responsibility has been at the centre of interest in many areas of economic research, studies using different levels of analysis. This paper analyses corporate social responsibility at the level of organisation within the banking system, where the issue of corporate social responsibility disclosure comes under the spotlight with the emergence of the global economic crisis. The purpose of the study is twofold: to examine whether Croatian banks' online corporate social responsibility reporting depends upon their market share, and whether it focuses on community related information. Using website content analysis of all twenty-eight banks currently operating in the Croatian banking sector, corporate social responsibility disclosure is categorised in terms of themes (environment, human resources, customers and products, and community involvement). The research findings reveal that the level of Croatian banks' online CSR disclosure is largely dependent on banks' market share. On the other hand, results indicate that Croatian banks are mainly reporting on activities related to customers and products, followed by those, which imply community involvement. Human resources and environmental initiatives receive the least amount of attention. The results of the study can be used to more deeply comprehend and understand banks' corporate social responsibility as a business philosophy that contributes to organisational performance and building trust between market participants.

Keywords: corporate social responsibility, online reporting, banks, Croatia

\author{
JEL: G21, M14
}

1 This work has been supported by the University of Rijeka under the projects: Approaches and Methods of Cost and Management Accounting in Croatian Public Sector (No. 13.02.1.2.09) and Tax System and Socio-economic Relations in the Croatian Society (No. 13.02.1.2.02). 


\section{Introduction}

Corporate social responsibility (CSR) refers to companies taking responsibility for their impact on society. The recent economic crisis and political turmoil brought more pressure from stakeholders regarding information about companies' responsible behaviour (Orlitzky, Siegel, \& Waldman, 2011; Pérez \& Bosque, 2015), especially among banks which have a significant influence on economy and society through their role of financial intermediaries.

This has resulted in a growing number of empirical studies aimed at assessing corporate social responsibility reporting in the banking sector. Their findings revealed that the level of CSR reporting depends greatly upon bank size (Branco \& Rodrigues, 2006, Gao, Heravi, \& Xiao, 2005; Hossain, 2008; Kiliç, 2016). Also, regarding the nature of CSR reporting, the studies indicated that banks primarily disclose community related information, followed by employee related, environmental and other information (Вranco \& Rodrigues, 2006; Gao et al., 2005; Hinson, Boateng, \& Madichie, 2010; Kiliç, 2016; Scholtens, 2009). However, although corporate websites have become the primary media for CSR disclosure (Moreno \& Capriotti, 2009), there are few international studies that examine online corporate social responsibility reporting by banks (Kiliç, 2016, p. 551). Since domestic authors have been mainly focused on the largest banks (Cerović, 2016; Cerović, Šegota, \& Maradin, 2016; Kundid, 2012), this study seeks to make a step forward, and include the entire Croatian banking sector.

The paper will try to answer the following questions: 'Is there a positive relationship between CSR reporting and bank size?' and 'Are banks primarily disclosing information regarding community involvement?' Using website content analysis of all twenty-eight banks currently operating in the Croatian banking market, corporate social responsibility disclosure is categorised in terms of themes (environment, human resources, customers and products, and community involvement).

The remainder of this study is organized as follows. The next section provides literature review on CSR concept, activities and reporting, followed by an extensive description of research methodology. The research results are discussed in the fourth section. The final part summarizes conclusions, implications and limitations of the study.

\section{Literature Review}

\subsection{Conceptual Framework of Corporate Social Responsibility}

The starting point for describing corporate social responsibility (CSR) is the stakeholder theory (Freeman, Wicks, \& Parmar, 2004) which says that a manager's duty is to balance the shareholders' financial interests against the interests of other stakeholders inside and outside the company. Such a paradigm shift is in contradiction with profit maximization as the basic 
business principle in traditional economic theory since Adam Smith, which in recent times is observed through the neoclassical perspective of Milton Friedman. Accordingly, the aim of corporate social responsibility is building reputation and achieving positive operating results. On the other hand, according to the legitimacy theory as another theoretical stronghold of corporate social responsibility, CSR reporting may be defined as the way organizations justify the reasons for their survival, profitability or actions, and build their reputation by paying a debt to society (Hinson et al., 2010). CSR reporting may be seen as a function of gaining and maintaining organizational legitimacy.

To date there is no generally accepted definition of the corporate social responsibility (Hyun, Yang, Jung, \& Hong, 2016). A. B. Carroll (1999, p. 289) identifies four areas that make up a corporate social responsibility pyramid: legal, economic, ethical and philanthropic. Vogel $(2005$, p. 4) defines corporate social responsibility as policies and programs that go beyond legal obligations in response to pressure of growing public expectations and, therefore, this kind of information is often subjective and biased (Scholtens, 2009, p. 163). Aguinis (2011, p. 855) defines CSR as contextual conditioned organizational activities and policies that take into account stakeholders' expectations, and reporting on social, environmental and financial performance measures (triple bottom line). Such a definition is accepted as well by Aguilera, Rupp, Williams, and Ganapathi (2007) who advocate a multi-level approach in studying corporate social responsibility. The European Commission has previously defined CSR as 'a concept whereby enterprises integrate social and environmental concerns in their business activities and in their relationships with stakeholders on a voluntary basis'. Their 2011 definition says it is 'the responsibility of enterprises for their impact on society'.

Regardless of its definition, CSR implies voluntary activities of enterprises that have a strong influence on stakeholder behaviour (investors, employees, consumers) and local community, which is ultimately reflected in organizational success. By building trust among stakeholders, CSR has a positive effect on enterprise reputation (Brammer \& Pavelin, 2006) and its operating results (Orlitzky et al., 2011; Рorter \& Кгаmer, 2011).

On the other hand, there are authors who are critical of corporate social responsibility in that it is being misused by organizations for the purpose of money laundering or disguising irregularities in operations (Martínez-Ferrero, Banerjee, \& García-Sánchez, 2016).

\subsection{CSR Activities by Banks}

Corporate social responsibility was for a long time considered through the prism of environmental protection. Banks, therefore, with minimal environmental impacts, were excluded from CSR studies (Вranco \& Rodrigues, 2006). However, there are valid reasons for their inclusion. Through financing, 
banks may opt not to support industrial activity that causes environmental pollution. Also, banks and other financial institutions are large consumers of paper and energy, and produce waste. Banks can have a major influence on society through financing industries that support unethical activities such as smuggling of arms, diamonds and the like (Shen, Wu, Chen, \& Fang, 2016). Also, according to Wu and Shen (2013), during the financial crisis, governments of many countries financed recovery of banks using public or state funds and the role of banks in corporate social responsibility is to compensate for the funds spent. Furthermore, in many countries banks are exempt from tax (VAT). Finally, corporate social responsibility role of banks is determined by their positive influence on building trust among customers and reputation (Shen et al., 2016) as well as achieving financial success (Nollet, Fillis, \& Mitrokostas, 2016).

There are significant differences in the type of socially responsible activity depending on sector and national context (Gjølberg, 2009). A modern CSR practice in banks is focused on investment policy - as the external aspect of corporate social responsibility, and resource utilization policy - as an internal aspect. In doing so, financing policies tend to include activities such as respect for human rights, refusing to provide financial services to organizations and regimes that violate human rights and freedoms, or for controversial social activities (money laundering, terrorism, trafficking in drugs and weapons, tobacco products, pornography industry, animal testing, production and trade of fur, organizing fights between animals, unsustainable exploitation of forest reserves, inappropriate breeding of farm animals, genetic manipulation, production of nuclear energy); and fostering environmentally conscious behaviour and ethical business standards. Resource utilization policies tend to ensure equal opportunities and possibilities in the workplace; selecting environmentally and ethically conscious suppliers; employee education on environmental and ethical aspects of business; environmentally-driven printing; saving energy and water; reducing HFC emissions; recycling policy; reducing use of fossil fuels and increasing consumption of renewable energy sources; ensuring environmental financial products and services (Carrasco, 2006; Cerović et al., 2016).

A total of thirty-six activities identified in the study on CSR practices in Hong Kong, conducted by Gao et al. (2005), have been categorized into the following six groups: a) environment; b) energy, health and safety; c) human resources; d) community; and e) fair business. Branco and Rodriguez (2006), who investigated social responsibility of banks in Portugal, defined a total of twenty-three CSR activities and categorized them into the following four groups: a) environment; b) human resources; c) customers and products; and d) community. In this paper, we apply Branco and Rodrigues's approach (2006) as a reference CSR categorization used in recent studies (Hinson et al., 2010; Jizi, Salama, Dixon, \& Stratling, 2014; Kiliç, 2016). 
Bank size, measured by market share or number of country branches (Branco \& Rodrigues, 2006; Gao et al., 2005; Hossain, 2008; Kiliç, 2016) is a key determinant of the level of CSR reporting. Along the lines of the stakeholder theory, this can be explained by pressures coming from a wider range of stakeholders, while the legitimacy theory suggests corporate social responsibility is the side effect of profitability and large organizations require a higher level of social responsibility, or at least a dialogue with the general public.

\subsection{CSR Reporting}

Socially responsible activities undertaken by enterprises have a purpose only when disclosed and visible to interest groups and the general public. CSR activities may be disclosed through CSR reports that, given the voluntary basis, can testify about the company acting honestly and transparently, and that cares for the society in which it operates. CSR reporting can be defined as systematic communication of enterprises with stakeholders on their social and environmental impact not included in their financial statements (Schreck, 2013). Such a definition is in accordance with the triple bottom line reporting (Elkington, 1997). CSR reports are known under different names such as Environmental Report, Triple Bottom Line Report, Sustainable Development Report, Corporate Social Responsibility Report and other.

With growing expectations of interest groups regarding information on corporate social responsibility (Orlitzky et al., 2011), CSR reporting is continuously increasing both in terms of quantity and quality. In the 70's of the last century mainly environmental information was reported (Gatti \& Seele, 2014), while today enterprises are reporting on their social, economic and environmental initiatives (Trevino \& Nelson, 2010).

The process of globalization coupled with advances in information technology led to corporate websites becoming the primary media for CSR reporting (Moreno \& Capriotti, 2009), particularly in large enterprises and multinational corporations (Esrock \& Leichty, 2000). The advantage of the Internet or corporate websites over traditional communication channels (annual reports, brochures, television) is reflected in an interactive, efficient and rapid transmission of information (Hinson et al., 2010) to different groups of stakeholders at the same time (Esrock \& Leichty, 2000).

\section{Research Methodology}

As a research technique, the paper applies content analysis of banks' websites. The rationale behind using this method is the following: 1) the process of globalization coupled with advances in information technology led to corporate websites becoming the primary media for CSR reporting (Moreno \& Capriotti, 2009); 2) banks' websites can disclose more information about CSR compared to annual reports as traditional communication channels 
(Douglas, 2004); and 3) content analysis is the dominant method used to examine online CSR disclosure (Patten, 2002) allowing classification of CSR activities in different categories.

Content analysis is a research method that provides systematic evaluation of symbolic content of all forms of written communication (Bauer, 2000; Kolbe \& Burnett 1991). Hsieh and Shannon (2005) define content analysis as a research method for the subjective interpretation of the content of text data through the systematic classification process of coding and identifying themes or patterns. According to Krippendorf (2004, p. 18), content analysis is 'a research technique for making replicable and valid references from data to their contexts'.

There are five basic steps in the content analysis process, adapted to website analysis according to guidelines offered by Krippendorf (2004) and McMillan (2000, p. 81): 1) formulating research questions and hypotheses; 2 ) selecting a sample; 3) defining coding categories; 4) coding the content; and 5) analysing and interpreting research findings.

\subsection{Research Objectives and Hypotheses}

The paper analyses corporate social responsibility reporting in Croatia's banking sector. More specifically, it identifies and categorizes CSR information disclosed by banks, and measures the level of their online reporting.

Based on an extensive literature review, the following hypotheses have been formulated:

$\mathrm{H} 1$ There is a positive relationship between corporate social responsibility reporting and bank size in terms of market share.

H2 Banks are primarily disclosing information regarding community involvement.

\subsection{Research Sample}

Research sample included websites of all banks belonging to the Croatian banking sector comprising of twenty-eight banks, of which one savings bank (Croatian National Bank, 2015). Due to their specific structure and role housing savings banks and the Croatian Bank for Reconstruction and Development were not included in the study.

Based on a market share criterion, the Croatian National Bank distinguishes between three types of banks - large, medium and small banks:

- Large banks with a market share above 5\%;

- Medium-sized banks with a market share of between 1 and 5\%; and

- Small banks with a market share of less than $1 \%$. 
Accordingly, the sample consisted of six large, three medium and nineteen small banks.

Given the websites' changing update frequency (Vilar \& Simão, 2015), the research was carried out in the same period - August 2016.

\subsection{Defining Coding Categories}

McMillan (2000, p. 81) defines two basic units of measurement in analysing the content of websites: coding units and context units. The coding units are the smallest segment of content counted and scored in the content analysis (e.g. words). The context units are the body of material surrounding the coding unit (e.g. paragraph, article, section), commonly named units of analysis.

In this research, coding units are related to CSR activities classified, according to Branco and Rodrigues's approach (2006), into four categories:

1. Environment (environmental policy, environmental management, lending and investment policy, conservation of natural resources and recycling activities, sustainability, energy conservation business practices);

2. Human resources (employee health and safety, employment of women or minorities, employee training, employee benefits and remuneration, employee profiles, employee share purchase scheme, employee morale, industrial relations);

3. Customers and products (product quality, customer satisfaction, provision for disabled and aged);

4. Community involvement (charitable donations, support for education, arts and culture and public health, sponsorship of sports and recreational projects).

Context units represent website sections that reveal accessibility or availability of CSR information. Information on CSR activities were searched under the following website sections: a) Home; b) About Us, c) Social Responsibility / Sustainable Development / Sustainability, d) Investor Relations, e) Career, f) Complaints. Namely, coding the entire website would be time-consuming and would introduce biases based on website size (Ho, 1997). Also, annual reports and financial statements were not taken into account. Lastly, as suggested by McMurtrie (2001), external links as well as links to various publications such as product catalogues were excluded from analysis.

\subsection{Coding the Content}

The coding process was carried out using dichotomous scale with two values to determine the existence of category on the website: 0 = category does not exist and 1 =category exists. If a category appears in several locations, it is counted only once. If a category relates several activities, it counts more times (for each activity separately). Proceeding in this way, 
based on previous research findings (Branco \& Rodrigues, 2006; Hinson et al., 2010), a CSR reporting index was obtained. Assuming that each category is equally important, scores for each bank are added up and not weighted. It should be noted that the described system does not necessarily reflect the quality of CSR activities, but their frequency (Zeghal \& Ahmed, 1990, p. 42).

\subsection{Data Analysis and Interpretation}

Data were analysed and interpreted using methods of descriptive statistics and correlation analysis. Data analysis was performed using SPSS Statistics 23.

Descriptive statistics was used to describe the research sample and determine the level of CSR reporting as well as proportions of CSR activities, which tested the hypothesis $\mathrm{H} 2$. Correlation analysis was used to examine relationship between the level of CSR reporting and bank size, which tested the hypothesis $\mathrm{H} 1$.

\section{Research Findings}

Not all banks in the Croatian banking sector are disclosing online information on corporate social responsibility. The content analysis revealed that 24 banks (85.71\%) provided CSR information through their websites. Of these, only two banks (7.14\%) published a separate report on corporate social responsibility.

Table 1. Descriptive statistics

\begin{tabular}{|l|c|c|c|c|c|}
\hline & $\mathrm{N}$ & Minimum & Maximum & Mean & $\begin{array}{c}\text { Standard } \\
\text { deviation }\end{array}$ \\
\hline CSR reporting (\%) & 28 & 0.00 & 75.86 & 20.32 & 24.78 \\
\hline
\end{tabular}

Data presented in Table 1 show that online communication about CSR activities among banks varies considerably between banks, ranging from a minimum of $0.00 \%$ to a maximum of $75.86 \%$, or $20.32 \%$ on average. The standard deviation (24.78) indicates a high dispersion within the sample.

A recently published comprehensive study on CSR practices of banks in fortyfour developing countries (Hu \& Scholtens, 2014) shows that CSR reporting in Croatian banking sector (15\%) falls near the middle of the scale ranking 20th. Scholten's previous (2009) work revealed that developed countries had a much higher level of CSR reporting: from the highest in the Netherlands (85\%), Germany (81\%), France (80\%) and the UK (80\%) to the lowest in Japan (62\%), Italy (61\%) and Sweden (37\%).

\subsection{Levels of CSR Reporting}

The content analysis identified a total of twenty-nine activities that form the basis for the calculation of the CSR reporting index. 
Table 2 shows that the level of CSR reporting is determined by the size of the bank - as measured by its market share.

Table 2. CSR reporting index by bank size

\begin{tabular}{|l|r|c|c|c|c|}
\hline Bank size & N & Mean & $\begin{array}{c}\text { Standard } \\
\text { deviation }\end{array}$ & Minimum & Maximum* \\
\hline Large & 6 & 13.50 & 7.53 & 6 & 21 \\
\hline Medium & 3 & 15.33 & 8.33 & 6 & 22 \\
\hline Small & 19 & 1.95 & 1.90 & 0 & 8 \\
\hline Total & 28 & 5.86 & 7.19 & 0 & 22 \\
\hline
\end{tabular}

* The maximum theoretical value of the index is 29 .

Calculated CSR reporting indexes indicate that medium-sized banks delivered the most CSR information (mean value of 15.33), followed by big banks (mean value of 13.50), while small banks disclosed least information regarding their CSR activities (mean value of 1.95). However, the greatest fluctuations were observed in the group of medium-sized banks with indexes ranging from 6 to 22 points. While only one medium-sized bank disclosed 22 CSR activities, the other two only reported 6 of them. On the other hand, in the group of big banks, half of them have indexes between 19 and 21 .

Table 3. Correlation analysis

\begin{tabular}{|c|c|c|c|c|}
\hline & & & Bank size & $\begin{array}{l}\text { CSR reporting } \\
\text { index }\end{array}$ \\
\hline \multirow{6}{*}{$\begin{array}{l}\text { Spearman's } \\
\text { correlation } \\
\text { coefficient }\end{array}$} & \multirow{3}{*}{ Bank size } & $\begin{array}{l}\text { Correlation } \\
\text { coefficient }\end{array}$ & 1.000 & $.727^{* *}$ \\
\hline & & $\begin{array}{l}\text { Significance } \\
\text { (two-tailed) }\end{array}$ & . & .000 \\
\hline & & $\mathrm{N}$ & 28 & 28 \\
\hline & \multirow{3}{*}{$\begin{array}{l}\text { CSR reporting } \\
\text { index }\end{array}$} & $\begin{array}{l}\text { Correlation } \\
\text { coefficient }\end{array}$ & $.727^{* *}$ & 1.000 \\
\hline & & $\begin{array}{l}\text { Significance } \\
\text { (two-tailed) }\end{array}$ & .000 & . \\
\hline & & $\mathrm{N}$ & 28 & 28 \\
\hline
\end{tabular}

** Correlation is significant at 0.01 (two-way).

Correlation coefficient of $0.727(p<0.01)$ shows a statistically significant, strong and positive relationship between online CSR reporting and bank size. This argument confirmed the hypothesis $\mathrm{H} 1$.

The results confirmed previous findings from related studies in domestic (Hernaus \& Stojanović, 2015; Kundid \& Rogošić, 2011; Rogošić \& Kundid, 2012) and international literature (Branco \& Rodrigues, 2006, Gao et al., 2005; Hossain, 2008; Kiliç, 2016), revealing that bank size is the determinant of social responsibility disclosure. The highest commitment of the largest banks may be explained by their nominal level of legitimacy, in response to rising 
expectations coming from a wide range of stakeholders. The results of this study revealed that medium-sized banks delivered more CSR reports than the largest banks, which can be viewed as a step forward in terms of awareness of the possible outcomes of socially responsible behaviour.

\subsection{CSR Activities by Banks}

A total of 29 socially responsible activities were identified by adding to Branco and Rodrigues's model (2006), which consists of 23 activities, 6 more activities specific to national context of the surveyed banks, namely: information on kindergartens and parental leave, employee recreation \& sport (Human Resources); education for clients and citizens (Customers and products); student recruitment; caring for children and young people; and supporting local economic development (Community). As mentioned, all the activities are classified into four categories: 1) Environment; 2) Human resources; 3) Customers and products, and 4) Community involvement.

According to the research findings presented in Table 4, it can be concluded that the hypothesis $\mathrm{H} 2$ has not been confirmed. In other words, Croatian banks mainly (37.07\%) reported on CSR activities focused on customers and products, followed by those which implied community involvement (17.24\%), while human resources (14.73\%) and environmental issues (14.94\%) received the least amount of attention, to an almost equal extent. Croatian banks most often disclosed information related to product quality (75.86\%) and customer satisfaction (58.62\%). These research findings are in line with similar research on Croatian banks (Kundid (2012), Rogošić \& Kundid, 2012).

In category 'Customers and products', two-thirds of banks (75.86\%) reported on activities focused on product quality, and more than a half (58.62\%) promoted customer satisfaction. The importance of helping clients build financial literacy has been recognized by $10.34 \%$ banks. Only one bank (3.45\%) reported on provisions and benefits for the elderly and people with special needs.

Category 'Community involvement' reveals that banks are largely supporting humanitarian projects (31.03\%) and those promoting sport (27.59\%), arts and culture (27.59\%), and education (20.69\%), followed by activities which support caring for children and young people (10.34\%). Less represented (6.90\%) аге public health activities, employment of students and development of local economy.

In category 'Environment', banks tend to report on environment policy and investment and financing policy (20.69\%), sustainability (17.24\%), conservation of natural resources, recycling and conservation of energy in business (13.79\%), and environmental management (3.45\%). 
Table 4. Socially responsible activities by banks

\begin{tabular}{|c|c|c|c|}
\hline Category & CSR activities & $\begin{array}{c}\text { Number of } \\
\text { banks }\end{array}$ & $\begin{array}{c}\text { Proportion } \\
(\%)\end{array}$ \\
\hline \multirow{7}{*}{ 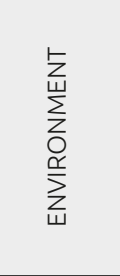 } & Environmental policy & 6 & 20.69 \\
\hline & Environmental management & 1 & 3.45 \\
\hline & Lending and investment policy & 6 & 20.69 \\
\hline & Conservation of natural resources and recycling activities & 4 & 13.79 \\
\hline & Sustainability & 5 & 17.24 \\
\hline & Energy conservation business practices & 4 & 13.79 \\
\hline & Average & & 14.94 \\
\hline \multirow{12}{*}{ 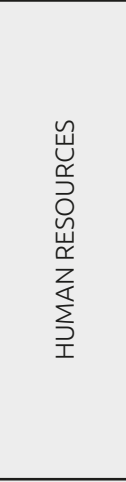 } & Employee health and safety & 4 & 13.79 \\
\hline & Employment of women or minorities & 4 & 13.79 \\
\hline & Employee training & 11 & 37.93 \\
\hline & Employee benefits & 4 & 13.79 \\
\hline & Employees remuneration & 5 & 17.24 \\
\hline & Employee profiles & 0 & 0.00 \\
\hline & Employee share purchase scheme & 0 & 0.00 \\
\hline & Employee morale & 10 & 34.48 \\
\hline & Industrial relations & 5 & 17.24 \\
\hline & Information on kindergartens and parental leave* & 2 & 6.90 \\
\hline & Employee recreation \& sport* & 2 & 6.90 \\
\hline & Average & & 14.94 \\
\hline \multirow{5}{*}{ 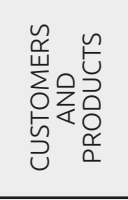 } & Product quality & 22 & 75.86 \\
\hline & Customer satisfaction & 17 & 58.62 \\
\hline & Provision for disabled, aged customers & 1 & 3.45 \\
\hline & Education for clients* & 3 & 10.34 \\
\hline & Average & & 37.07 \\
\hline \multirow{9}{*}{ 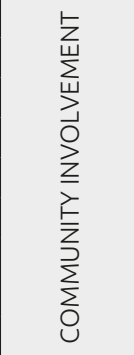 } & Charitable donations & 9 & 31.03 \\
\hline & Support for education & 6 & 20.69 \\
\hline & Support for arts and culture & 8 & 27.59 \\
\hline & Support for public health & 2 & 6.90 \\
\hline & Sponsoring sports or recreational projects & 8 & 27.59 \\
\hline & Student recruitment* & 2 & 6.90 \\
\hline & Caring for children and young people* & 3 & 10.34 \\
\hline & Local economic development support* & 2 & 6.90 \\
\hline & Average & & 17.24 \\
\hline
\end{tabular}

* Characteristic activities for the Croatian banking sector

In category 'Human Resources' the most numerous were activities focused on employee training (37.93\%) and employee morale (34.48\%), followed by those focused on rewarding employees and their relationships with industry (with the same percentage of 17.24). Further activities focused on employment of women and minorities and employee benefits (all 13.79\%). Only two (largesized) banks paid attention to work-life balance as well as organized sports and recreational activities of employees (6.90\%). No information on employee share purchase scheme or employee profiles was found.

As can be seen from the foregoing, Croatian banks are mainly reporting on their CSR activities belonging in category 'Customers and products', 
neglecting other dimensions of corporate social responsibility. This can be explained by the fact that banks which operate in Croatia, as a transitional country, still do not have enough knowledge about the long-term effects of (not) reporting on environmental issues, professional and personal development of employees, and community engagement.

International research findings reveal that the structure of a bank's practiced CSR activities considerably depend on a country's level of economic development. In developing countries (Hu \& Scholtens, 2014) banks are focusing their CSR efforts on the community (58\%), with environmental issues receiving much less attention (6\%). In developed countries (Scholtens, 2009), banks are equally focused on contributing to the community $(93.77 \%)$ and the environment (77.30\%).

\section{Conclusion}

The purpose of the study was to examine whether Croatian banks' online corporate social responsibility reporting depends upon their market share, and whether it focuses on community related information - as suggested by the relevant empirical research in the field. Using website content analysis of all twenty-eight banks currently operating in the Croatian banking sector, corporate social responsibility disclosure was categorised in terms of themes (environment, human resources, customers and products, and community involvement).

The research results affirmed previous studies that the level of online CSR reporting is positively related to bank size as measured by market share, thus confirming the first hypothesis. On the other hand, it was found that Croatian banks are mainly disclosing CSR information regarding customers and products, which resulted in rejection of the second hypothesis.

Limitations associated with the study are related to the characteristics of content analysis, sample size and the nature of online social responsibility reporting. Firstly, the dichotomous technique used to code content data does not necessarily reflect the quality of banks' CSR activities, but their frequency or visibility via the website. Furthermore, since there is no relevant legislation on CSR reporting, the research relied on self-reported information collected from the banks that is often biased. Finally, the results are limited due to the relatively small sample size which, however, does include all the banks in the croatian banking sector.

A scientific contribution of the conceptual part of the paper is reflected in the development of scientific thought on corporate social responsibility with particular reference to its application on the banking sector. Seen from empirical and applicability aspects, the paper which presents the main features of online corporate social responsibility reporting in the Croatian banking sector, offers recommendations and guidelines to banks' management 
teams and all interested parties. By understanding and improving corporate social responsibility awareness and practice, banks will be able to reduce the possible negative impact that interest groups may have on their business, while raising reputation and financial performance.

Sanda Grudić Kvasic is a teaching assistant at the Faculty of Tourism and Hospitality Management at University of Rijeka, Croatia. As a member of the Department of Management, she has teaching and research obligations for the undergraduate courses Management and Business ethics. She has written and co-authored over ten scientific articles, presented papers at international scientific conferences and participated in several research projects in the field of tourism and economics. Her current research interests are: leadership, positive organizational behaviour and business ethics.

Ljerka Cerovic, PhD is a full professor at Faculty of Economics, University of Rijeka, Croatia. She teaches Microeconomics and related courses at the undergraduate, graduate and postgraduate study, and is head of department for theoretical economics. She has participated and exhibited in numerous conferences in the country and abroad, and has published more than 60 scientific and expert papers in national and international publications. In addition, she was a president and is a member of body of professional and higher-education associations. She is a member of scientific-expert committees for the organization of national and international scientific conferences, and a member of the editorial and reviewers' board of national and international journals.

Bojana Olgić Draženović, PhD is an assistant professor at Faculty of Economics, University of Rijeka, Croatia. She teaches courses on undergraduate studies: Financial Markets and Institutions, Monetary Economics and on graduate studies: Financial Markets and Institutions and Investment Analysis. She is a member of Department of Banking and Finance. She has participated in several scientific and research projects and participated in several scientific conferences in the field of economy in the country and abroad. She has published over 30 scientific and professional articles. Her current research interests focus on areas of financial markets and institutions as well as financial regulation and supervision. 


\section{References}

Aguilera, R. V., Rupp, D. E., Williams, C. A., \& Ganapathi, J. (2007). Putting the S back in corporate social responsibility: A multilevel theory of social change in organizations. Academy of Management Review, 32(3), 836-863. doi:10.5465/AMR.2007.25275678

Aguinis H. (2011). Organizational responsibility: Doing good and doing well. In S. Zedeck. (Ed.), APA Handbook of Industrial and Organizational Psychology (pp. 855-879). Washington, DC: American Psychological Association. doi:10.1037/12171-024

Bauer, M. W. (2000). Classical content analysis: A review. In M. W. Bauer \& G. Gaskell (Eds.), Qualitative Researching with Text, Image and Sound: A practical handbook (pp. 131-151). London: Sage. doi:10.4135/9781849209731.n8

Brammer, S. J., \& Pavelin, S. (2006). Corporate reputation and social performance: The importance of fit. Journal of Management Studies, 43(3), 435-455. doi:10.1111/j.1467-6486.2006.00597.x

Branco, M. C., \& Rodrigues, L. L. (2006). Communication of corporate social responsibility by Portuguese banks: A legitimacy theory perspective. Corporate Communications: An International Journal, 11(3), 232-248. doi:10.1108/13563280610680821

Carrasco, I. (2006). Ethics and banking. International Advances in Economic Research, 12(1), 43-50. doi:10.1007/s11294-006-6131-1

Carroll, A. B. (1999). Corporate social responsibility evolution of a definitional construct. Business \& Society, 38(3), 268-295. doi:10.1177/000765039903800303

Cerović, Lj. (2016). An overview of socially responsible activities of the largest banks in Croatian banking market. Proceedings of 5 th International Conference "Vallis Aurea" Focus on: Research \& Innovation. Polytechnic in Požega (pp. 53-62). Požega: Croatia \& DAAAM International Vienna.

Cerović, Lj., Šegota, A., \& Maradin, D. (2016). Social responsibility in the Croatian banking sector. Proceedings of 5 th International Conference "Vallis Aurea" Focus on: Research \& Innovation. Polytechnic in Požega (pp. 63-70). Požega: Croatia \& DAAAM International Vienna.

Douglas, A., Doris, J., \& Johnson, B. (2004). Corporate social reporting in Irish financial institutions. The TQM Magazine, 16(6), 387-395. doi:10.1108/09544780410563301

Elkington, J. (1997). Cannibals with Forks: The Triple Bottom Line of 21 Century Business. Oxford: Capstone Publishing.

Esrock, S. L., \& Leichty, G. B. (2000). Organization of corporate web pages: Publics and functions. Public Relations Review, 26(3), 327-344. doi:10.1016/S0363-8111(00)00051-5

European Commission. (2011). A renewed EU strategy 2011-14 for Corporate Social Responsibility. Retrieved 1. 7. 2016., from: http://eur-lex.europa.eu

Freeman, R. E., Wicks, A. C., \& Parmar, B. (2004). Stakeholder theory and "the corporate objective revisited". Organization Science, 15(3), 364-369. doi:10.1287/orsc.1040.0066

Gatti, L., \& Seele, P. (2014). Evidence for the prevalence of the sustainability concept in European corporate responsibility reporting. Sustainability Science, 9(1), 89-102. doi:10.1007/s11625-013-0233-5 
Gao, S. S., Heravi, S., \& Xiao, J. Z. (2005, June). Determinants of corporate social and environmental reporting in Hong Kong: a research note. Accounting Forum, 29(2), 233-242. doi:10.1016/j.accfor.2005.01.002

Gjølberg, M. (2009). Measuring the immeasurable?: Constructing an index of CSR practices and CSR performance in 20 countries. Scandinavian Journal of Management, 25(1), 10-22. doi:10.1016/j.scaman.2008.10.003

Hernaus, A. I., \& Stojanovic, A. (2015). Determinants of bank social responsibility: case of Croatia. E+ M Ekonomie a Management, 18(2), 117-134. doi:10.15240/tul/001/2015-2-009

Hinson, R., Boateng, R., \& Madichie, N. (2010). Corporate social responsibility activity reportage on bank websites in Ghana. International Journal of Bank Marketing, 28(7), 498-518. doi:10.1108/02652321011085176

HNB, Privremeni nerevidirani podaci za kreditne institucije na dan 31.12.2015. Retrieved 2. 8. 2016., from https://www.hnb.hr/statistika/statisticki-podaci/

Ho, J. (1997). Evaluating the World Wide Web: A global study of commercial sites. Journal of Computer Mediated Communication, 3(1). doi: 10.1111/j.1083-6101.1997.tb00066.x

Hossain, M. (2008). The Extent of Disclosure in Annual Reports of Banking Companies: The Case of India. European Journal of Scientific Research, 23(4), 659-680.

Hsieh, H. F., \& Shannon, S. E. (2005). Three approaches to qualitative content analysis. Qualitative Health Research, 15(9), 1277-1288. doi:10.1177/1049732305276687

Hu, V. I., \& Scholtens, B. (2014). Corporate social responsibility policies of commercial banks in developing countries. Sustainable Development, 22(4), 276-288. doi:10.1002/sd.1551

Hyun, E., Yang, D., Jung, H., \& Hong, K. (2016). Women on Boards and Corporate Social Responsibility. Sustainability, 8(4), 300. doi:10.3390/su8040300

Jizi, M. I., Salama, A., Dixon, R., \& Stratling, R. (2014). Corporate governance and corporate social responsibility disclosure: Evidence from the US banking sector. Journal of Business Ethics, 125(4), 601-615. doi:10.1007/s10551-013-1929-2

Kiliç, M. (2016). Online corporate social responsibility (CSR) disclosure in the banking industry: evidence from Turkey. International Journal of Bank Marketing, 34(4), 550-569. doi:10.1108/IJBM-04-2015-0060

Kolbe, R. H., \& Burnett, M. S. (1991). Content-analysis research: An examination of applications with directives for improving research reliability and objectivity. Journal of Consumer Research, 18(2), 243-250. doi:10.1086/209256

Krippendorff, K. (2004). Content analysis: An introduction to its methodology. Beverly Hills, CA: Sage.

Kundid, A. (2012). Društveno odgovorno poslovanje banaka u Republici Hrvatskoj. Ekonomska misao i praksa, 21(2), 497-528.

Kundid, A. \& Rogošić, A. (2011). Bank Online Reporting: Comparative Advantage, Formalism or Fashion? Global Business \& Economics Anthology, 2(2), 500-518.

Martínez-Ferrero, J., Banerjee, S., \& García-Sánchez, I. M. (2016). Corporate social responsibility as a strategic shield against costs of earnings management practices. Journal of Business Ethics, 133(2), 305-324.

doi:10.1007/s10551-014-2399-x 
McMillan, S. J. (2000). The microscope and the moving target: The challenge of applying content analysis to the World Wide Web. Journalism \& Mass Communication Quarterly, 77(1), 80-98. doi:10.1177/107769900007700107

McMurtrie, T. (2001). Disclosure through the looking glass. In 3rd APIRA Conference, Adelaide University, July 2001.

Moreno, A., \& Capriotti, P. (2009). Communicating CSR, citizenship and sustainability on the web. Journal of Communication Management, 13(2), 157-175. doi:10.1108/13632540910951768

Nollet, J., Filis, G., \& Mitrokostas, E. (2016). Corporate social responsibility and financial performance: A non-linear and disaggregated approach. Economic Modelling, 52, 400-407. doi:10.1016/j.econmod.2015.09.019

Orlitzky, M., Siegel, D. S., \& Waldman, D. A. (2011). Strategic corporate social responsibility and environmental sustainability. Business \& Society, 50(1), 6-27. doi:10.1177/0007650310394323

Patten, D. M. (2002). Give or take on the internet: an examination of the disclosure practices of insurance firm web innovators. Journal of Business Ethics, 36(3), 247-259. doi:10.1023/A:1014009229437

Pérez, A., \& Bosque, I. R. (2015). How customer support for corporate social responsibility influences the image of companies: Evidence from the banking industry. Corporate Social Responsibility and Environmental Management, 22(3), 155-168. doi:10.1002/csr.1331

Porter, M. E., \& Kramer, M. R. (2011). Creating shared value. Harvard Business Review, 89(1/2), 62-77.

Rogošić, A. (2014). Corporate social responsibility reporting of the banks in Bosnia and Herzegovina, Croatia and Montenegro. Theoretical and Applied Economics, 21(9 (598)), 71-82.

Rogošić, A., \& Kundid, A. (2012). Izvještavanje o društvenoj odgovornosti banaka u Hrvatskoj. Praktični menadžment, 3(5), 15-20.

Scholtens, B. (2009). Corporate social responsibility in the international banking industry. Journal of Business Ethics, 86(2), 159-175. doi:10.1007/s10551-008-9841-x

Schreck, P. (2013). Disclosure (CSR Reporting). In Encyclopedia of Corporate Social Responsibility (pp. 801-810). Berlin: Springer-Verlag. doi:10.1007/978-3-642-28036-8_145

Shen, C. H., Wu, M. W., Chen, T. H., \& Fang, H. (2016). To engage or not to engage in corporate social responsibility: Empirical evidence from global banking sector. Economic Modelling, 55, 207-225. doi:10.1016/j.econmod.2016.02.007

Trevino, L. K., \& Nelson, K. A. (2010). Managing Business Ethics. New York: John Wiley \& Sons.

Vilar, V. H., \& Simão, J. (2015). CSR disclosure on the web: major themes in the banking sector. International Journal of Social Economics, 42(3), 296-318. doi:10.1108/IJSE-10-2013-0240

Vogel, D. (2005). The Market for Virtue - The Potential and Limits of Corporate Social Responsibility. Washington DC: Brookings Institution Press.

Wu, M. W., \& Shen, C. H. (2013). Corporate social responsibility in the banking industry: Motives and financial performance. Journal of Banking \& Finance, 37(9), 3529-3547. doi:10.1016/j.jbankfin.2013.04.023

Zeghal, D., \& Ahmed, S. A. (1990). Comparison of social responsibility information disclosure media used by Canadian firms. Accounting, Auditing \& Accountability Journal, 3(1), 38-53. doi:10.1108/09513579010136343 


\subsection{Izvirni znanstveni članek}

\section{Spletno poročanje o družbeni odgovornosti gospodarskih družb v hrvaškem bančnem sektorju}

Na družbeno odgovornost gospodarskih družb (DOGD) se je dolgo gledalo skozi prizmo varstva okolja. Zato so bile banke z minimalnimi vplivi na okolje izključene iz raziskovanja DOGD. Vendarso nedavna ekonomska kriza in politični nemiri prinesli več pritiska interesnih skupin glede informacij o odgovornem vedenju gospodarskih družb, zlasti bank, ki imajo znaten vpliv na ekonomijo in družbo s svojo vlogo finančnih posrednikov. To se je odrazilo v naraščajočem številu empiričnih študij, usmerjenih $v$ doseganje poročanja o družbeni odgovornosti gospodarskih družb v bančnem sektorju. Njihove ugotovitve kažejo, da je raven poročanja o DOGD v veliki meri odvisna od velikosti banke. Prav tako v zvezi z naravo poročanja o DOGD študije nakazujejo, da banke najprej razkrijejo informacije, povezane s skupnostjo, čemur sledijo podatki, povezani z zaposlenimi, okoljem in druge informacije. Čeprav so spletne strani gospodarskih družb postale primarni medij za razkrivanje DOGD, obstaja nekaj mednarodnih raziskav, ki proučujejo spletno poročanje bank o družbeni odgovornosti gospodarskih družb.

Namen študije je bil dvojen: proučiti, ali je spletno poročanje hrvaških bank o družbeni odgovornosti gospodarskih družb odvisno od njihovega tržnega deleža in ali se osredotoča na informacije, povezane s skupnostjo. Z uporabo analize vsebine spletne strani vseh osemindvajsetih bank, ki trenutno delujejo v hrvaškem bančnem sektorju, je bilo razkritje družbene odgovornosti gospodarskih družb kategorizirano glede na teme (okolje, človeški viri, potrošniki in izdelki ter vključenost skupnosti).

Rezultati raziskave so pokazali, da vse banke v hrvaškem bančnem sektorju na spletu ne razkrivajo informacij o družbeni odgovornosti gospodarskih družb. Natančneje 24 bank $(85,71 \%)$ posreduje informacije o DOGD preko svojih spletnih strani. Med temi samo dve banki $(7,14 \%)$ objavljata ločeno poročilo o družbeni odgovornosti gospodarskih družb. Z drugimi besedami: spletna komunikacija o aktivnostih DOGD se znatno razlikuje med bankami in sega od najmanj 0,00 \% do največ 75,86 \% oziroma 20,32 \% v povprečju.

Poleg tega je korelacijska analiza potrdila statistično znatno, močno in pozitivno povezavo med spletnim poročanjem o DOGD in velikostjo banke in s tem potrdila predhodne raziskave. Izračunani indeksi poročanja o DOGD nakazujejo, da so srednje velike banke objavile največ informacij o DOGD (srednja vrednost 15,33), ki so jim sledile velike banke (srednja vrednost 13,50), medtem ko majhne banke razkrijejo najmanj informacij v povezavi z aktivnostmi DOGD (srednja vrednost 1,95). Vendar so bila največja nihanja 
opažena v skupini srednje velikih bank z indeksi med 6 in 22 točkami. Samo ena srednje velika banka razkrije 22 aktivnosti DOGD, drugi dve pa poročata o 6 izmed njih. V skupini velikih bank ima polovica od bank indekse med 19 in 21.

Po drugi strani pa je bilo s pomočjo analize vsebine spletne strani ugotovljeno, da hrvaške banke primarno ne razkrivajo informacij o DOGD v povezavi z vključitvijo skupnosti, kar je v nasprotju s prej omenjenimi študijami. Hrvaške banke namreč večinoma $(37,07 \%)$ poročajo o aktivnostih DOGD, ki se osredotočajo na potrošnike in izdelke, čemur sledijo informacije, ki nakazujejo vpletenost skupnosti (17,24 \%), medtem ko človeški viri $(14,73$ \%) in okoljska vprašanja (14,94 \%) v skoraj enaki meri prejemajo najmanj pozornosti.

Omejitve, povezane z raziskavo, so povezane z značilnostmi analize vsebine, velikostjo vzorca in naravo spletnega poročanja o družbeni odgovornosti gospodarskih družb. Dihotomna tehnika, ki se uporablja za kodiranje podatkov vsebine, ne odraža nujno kakovosti aktivnosti DOGD bank, ampak njihovo frekvenco ali prepoznavnost prek spletne strani. Poleg tega, ker ne obstaja ustrezna zakonodaja o poročanju o DOGD, se je raziskava naslonila na informacije samoporočanja, ki so jih posredovale banke in so pogosto pristranske. Na koncu pa so rezultati omejeni zaradi relativno majhnega vzorca, ki vključuje vse banke v hrvaškem bančnem sektorju.

Znanstveni prispevek konceptualnega dela članka se odraža v razvoju znanstvene misli o družbeni odgovornosti gospodarskih družb, s posebnim poudarkom na njeni uporabi v bančnem sektorju. Z empiričnega vidika in $z$ vidika uporabnosti ta prispevek ponuja priporočila in smernice $v$ povezavi s spletno komunikacijo o družbeni odgovornosti gospodarskih družb. Z razumevanjem in izboljšanjem prakse razkrivanja DOGD bodo banke lahko zmanjšale mogoč negativni vpliv, ki ga lahko imajo interesne skupine na njihovo poslovanje, medtem ko bodo dvignile ugled in finančno uspešnost. 